\title{
Analysis of the Relationship Between the Organizational Climate and Transformational Leadership Roles of the School Administrators*
}

\author{
Ahmet AYIK $^{* *} \quad$ Okan Dİş**
}

Received: 07 January 2014

Accepted: 06 April 2015

\begin{abstract}
In this research, the correlation between the transformational leadership roles of school administrators and climate of organization according to perceptions of teachers who officiate in primary schools was analyzed. The sample of this research consisted of 258 teachers who officiate in public primary schools in Yakutiye, Erzurum that subordinated to Ministry of Education in 2013-2014 educational years old. As data collection tools in research, ““'Organizational Climate Scale,”” and ““'Transformational Leadership Survey,”, was used. In this descriptive research, while analyzing the data was profited from standard deviation ,average, Pearson Product-Moment Correlation and multiple linear regression. Results of research showed that the transformational leadership roles of school administrators and climate of organization has a moderately significant correlation. The results of regression analysis predicted idealized effect, being inspiration and individualized concern sides of transformational leadership and supportive administrator behaviour side of climate of organization positively and meaningfully. School administrators' imperious behaviours and teachers' unconcerned behaviours sides of climate of organization predicted being inspiration side of transformational leadership. The results of research was discussed depending on improve climate of organization in schools and transformational leadership behaviours of school administrators.
\end{abstract}

Keywords: climate of organization, transformational leadership, primary organization administrators

\section{Extended Abstract}

Purpose and Significance: This study aims to analyze the relationship between the organizational climate and transformational leadership roles according to the perceptions of the teachers working in primary schools. Determining the relationship between the organizational climate and transformational leadership roles of the school administrators is important to understand which dimensions of the transformational leadership are related to which dimensions of school climate. School administrators who exhibit leadership behaviors create a positive atmosphere in the school and they can ensure the school to achieve its goals effectively. It is expected that the findings of the study will contribute to the literature when it is thought that the transformational leadership is important to create a positive climate.

Methods: Relational screening model, one of the screening models, is used in the study. In this study which is conducted in screening model, the relationships between the organizational climate and the transformational leadership are analyzed. The universe of

\footnotetext{
* This article was presented at 8th National Congress of Educational Administration, November 8-10, 2013, İstanbul, Turkey.

** Corresponding Author: Assist. Prof. Dr., Atatürk University, Erzurum, Turkey, ahmet.ayik@atauni.edu.tr

*** Atatürk University, Erzurum, Turkey, okandis25@gmail.com
} 
the study consists of teachers working in primary schools of Ministry of National Education in Yakutiye county town, Erzurum in 2012-2013 academic years.

The sample of the study consists of 258 primary school teachers from 15 primary schools selected with appropriate sampling method. The data collection tool of the study is threefold. The first part involves demographic information of the teachers such as gender, branch and professional seniority. The second part involves Transformational Leadership Questionnaire consisted of 37 items and 4 sub-dimensions; the third part involves Organizational Climate Questionnaire consisted of 39 items and 8 subdimensions. After having determined the arithmetic average mean values of the items in each sub-dimensions, a score was calculated for that factor to resolve the sub-problems of the study. Analysis was done according to these factor scores. Pearson productmoment correlation coefficient $(r)$ was used in calculating the relationship between the variables. However, multiple linear regression analysis was done to determine the prediction level of the independent variables on dependent variables. In interpreting the regression analysis, standardized Beta $(\beta)$ coefficients and t-test result related to their meaningfulness were considered. .05 meaningfulness level was based on in the analysis of the data.

Results: According to the perceptions of the teachers in the working group, it is seen that the highest average scores are in individual consideration dimension ( $\bar{x}=3,35)$, and the lowest average scores are in inspiration dimension $(\bar{x}=3,11)$ in terms of transformational leadership dimensions after analyzing the range related to the transformational leadership of the school managers and the organizational climate. Serinkan (2003) and Çelik (2010) also obtained similar results. After analyzing the range related to organizational climate, it can be seen that the highest scores are in the collegial behavior dimension $(\bar{x}=3,02)$, and the lowest scores are in the disengaged behavior dimension $(\bar{x}=2,03)$. In the study conducted by Tahaoğlu (2007), it is seen that the highest average is in production emphasis dimension, and the lowest one is in hindrance behavior dimension when analyzing the sub-dimensions of organizational climate. It was found out that there is a positive way meaningful relationship between the charisma dimension of the transformational leadership questionnaire and the supportive behavior $(\mathrm{r}=.76, \mathrm{p}<.01)$, directive behavior $(\mathrm{r}=.21, \mathrm{p}<.01)$, intimate behavior $(\mathrm{r}=.31, \mathrm{p}<.01)$ and collegial behavior $(\mathrm{r}=.39, \mathrm{p}<.01)$ dimensions of the organizational climate questionnaire; and between the intellectual stimulation dimension and supportive behavior ( $\mathrm{r}=.67, \mathrm{p}<.01)$, directive behavior $(\mathrm{r}=.30, \mathrm{p}<.01)$, intimate behavior $(\mathrm{r}=.32, \mathrm{p}<.01)$ and collegial behavior $(\mathrm{r}=.41, \mathrm{p}<.01)$ dimensions; and between the inspiration dimension and the supportive behavior $(\mathrm{r}=.73, \mathrm{p}<.01)$, directive behavior $(\mathrm{r}=.31, \mathrm{p}<.01)$, intimate behavior $(\mathrm{r}=.32, \mathrm{p}<.01)$ and collegial behavior $(\mathrm{r}=.35, \mathrm{p}<.01)$ dimension of organizational climate questionnaire; and between the individual consideration dimension and the supportive behavior $(\mathrm{r}=.74, \mathrm{p}<.01)$, directive behavior $(\mathrm{r}=.23, \mathrm{p}<.05)$, intimate behavior $(\mathrm{r}=.30, \mathrm{p}<.01)$ and collegial behavior dimensions. 
It was determined that there is a negative way, low level meaningful relationship between the charisma dimension of the transformational leadership questionnaire and the restrictive behavior $(\mathrm{r}=-.17, \mathrm{p}<.01$ and disengaged behavior $(\mathrm{r}=-.13, \mathrm{p}<.05)$; and between the inspiration dimension and the restrictive behavior $(\mathrm{r}=-.14, \mathrm{p}<.05)$; and between the individual consideration dimension and the restrictive behavior dimension $(\mathrm{r}=-.16, \mathrm{p}<.01)$ and disengaged behavior $(\mathrm{r}=-.15, \mathrm{p}<.05)$ dimensions of the organizational climate questionnaire.

It was found out that there is a positive way, medium level meaningful relationship between the total scores $(\mathrm{r}=.57, \mathrm{p}<.01)$ of the teachers participated in the research related to their perceptions about transformational leadership and organizational climate.

Discussion and Conclusions: It was found out that there is a meaningful relationship in a positive way between all dimensions of the transformational leadership questionnaire and supportive behavior, directive behavior, intimate behavior, collegial behavior dimensions of the organizational climate questionnaire. It was found out that there is a low level meaningful relationship in a negative way between charisma, inspiration and individual consideration dimensions of the transformational leadership questionnaire and restrictive behavior and disengaged behavior dimensions of the organizational climate questionnaire. It was determined that there is a positive way and middle level meaningful relationship between the total scores related to the perceptions of the teachers about transformational leadership and organizational climate. In his study, Tahaoğlu (2007) concluded in his study that generally there is a positive, linear, high level and meaningful relationship of the leadership roles of the school administrators on the organizational climate. It can be seen in the study of Şen and Yaşlığlu (2010) that there are meaningful relationships between the perceptions about transformational leadership and organizational climate.

The regression results showed that charisma, inspiration and individual consideration dimensions of the transformational leadership questionnaire all together predict the supportive behavior dimension of the organizational climate questionnaire in a meaningful level. It is seen that the inspiration dimension predicts the directive behavior dimension in a negative way, meaningful level. The individual consideration dimension predicts the disengaged behavior dimension in a meaningful level while the inspiration dimension predicts the disengaged dimension in a positive way, meaningful level.

The all dimensions of the transformational leadership questionnaire are not a meaningful predictor of the restrictive behavior and intimate behavior dimensions of the organizational climate questionnaire. It cannot be said that the charisma and intellectual stimulation dimensions are a meaningful predictor of the disengaged behavior dimension. The intellectual stimulation dimension predicts the collegial behavior dimension in a positive way and meaningful level. According to the results, the charisma, inspiration and individual consideration dimensions are not a meaningful predictor of the collegial behavior dimension. 


\title{
Okul Yöneticilerinin Dönüşümcü Liderlik Rolleri İle Örgüt İklimi Arasındaki İlişkinin İncelenmesi*
}

\author{
Ahmet AYIK ${ }^{* *} \quad$ Okan Díș**
}

Makale Gönderme Tarihi: 07 Ocak 2014

Makale Kabul Tarihi: 06 Nisan 2015

ÖZET: Bu araştırmada, ilköğretim kurumlarında görev yapan öğretmen algılarına göre, örgüt iklimi ile okul yöneticilerinin dönüşümcü liderlik davranışları arasındaki ilişki incelenmiştir. Araştırmanın örneklemi 2012-2013 eğitim-öğretim yılında Erzurum ili Yakutiye ilçesindeki Milli Eğitim Bakanlığına bağlı devlet ilköğretim kurumlarında görev yapmakta olan 258 öğretmenden oluşmaktadır. Araştırmada veri toplama aracı olarak, “Örgütsel İklim Ölçeği” ile "Dönüşümcü Liderlik Anketi” kullanılmıştır. Betimsel bir çalışma olan bu araştırmada verilerin çözümlenmesinde standart sapma, ortalama, Pearson Momentler Çarpım korelasyonu ve çoklu doğrusal regresyon analizinden faydalanılmıştır. Araştırmanın sonuçlarına göre, ilköğretim okul yöneticilerinin dönüşümcü liderlik özellikleri ile örgüt iklimi arasında orta düzeyde anlamlı bir ilişki bulunmuştur. Regresyon analizi sonuçları, dönüşümcü liderliğin idealleştirilmiş etki, esin kaynağı olma, bireyselleştirilmiş ilgi boyutlarının örgüt ikliminin destekleyici müdür davranışları boyutunu pozitif yönde ve anlamlı düzeyde yordadığını göstermiştir. Örgüt ikliminin emredici müdür davranışları ve umursamaz öğretmen davranışları boyutları dönüşümcü liderliğin esin kaynağı olma boyutu tarafından yordandığını göstermiştir.

Anahtar sözcükler: örgüt iklimi, dönüşümcü liderlik, ilköğretim kurumu yöneticileri

\section{Giriş}

Örgüt iklimi çeşitli şekillerde tanımlanmış ve ölçülmüştür. Etimolojik açıdan iklim (climate) sözcüğ̈̈ Yunanca'dan gelmekte ve eğilim anlamı taşımaktadır. 1960’lı yıllardan bu yana örgüt kuramcıları, araştırmacılar ve uygulayıcılar tarafindan çağdaş bir ilgi alanı olarak önem kazanan örgüt iklimi kavramı, bir örgütteki sosyal ve örgütsel değişkenlerle olan etkileşimler olarak ifade edilmektedir. Okul iklimi ise; okul içindeki insanların davranışlarını etkileyen okul içi çevreyle ilgili özelliklere ilişkin algıları ifade etmektedir (Şişman, 2012). Her okulun kendine özgü bir kişiliği vardır. Örgütsel iklim işte bu kişiliktir. Kişilik birey için ne ise iklim de örgüt için odur (Karataş, 2008).

Örgüt iklimi konusundaki çalışmalar incelendiğinde; örgütsel güvenin örgüt iklimine etkisinin olduğu (Yaşar, 2005); olumlu iklime sahip okulların daha az problem yaşadıkları (Gottfredson, Gottfredson, Payne ve Gottfredson, 2005); örgüt ikliminin motivasyon üzerine etkisi olduğu (Aksoy, 2006); çalışanların yaratıcılı̆̆ını destekleyen bir örgüt ikliminin, iş tatmini ve işten ayrılma niyetini belirleyen bir etken olduğu (Çekmecelioğlu, 2007); örgüt ikliminin oluşmasında yöneticilerin kişisel ve yönetsel özelliklerinin önemli olduğu (Yapıcıer, 2007); okul müdürlerinin etkililiği ile okul iklimi arasında ilişki olduğu (Karataş, 2008); mobbing ve örgüt iklimi arasındaki ilişki olduğu (Yılmaz, Özler ve Mercan, 2008); örgüt ikliminin etik olmayan davranışlar üzerine etkisi olduğu (Büte, 2011) sonuçlarına ulaşılmıştır.

Örgüt iklimi, kurumu diğer kurumlardan ayırır; çünkü örgüt; üyelerinin diğer örgüt üyeleri ile olan etkileşiminin, örgüt yapısının, politikalarının ve örgüt süreçlerinin

\footnotetext{
* Bu çalışma, 07-09 Kasım 2013 tarihleri arasında İstanbul'da düzenlenen 8. Ulusal Eğitim Yönetimi Kongresi’nde sunulan bildirinin genişletilmiş halidir.

** Sorumlu Yazar: Yrd. Doç. Dr., Atatürk Üniversitesi, Erzurum, ahmet.ayik@atauni.edu.tr

**** Atatürk Üniversitesi, okandis25@gmail.com
} 
sonucunda biçimlendirdikleri organizasyonun genel izleniminden oluşmaktadır. $\mathrm{Bu}$ da sadece o örgütte var olan özellikleri bize gösterir (Önen, 2008). Taymaz’a (2007) göre bir okulda sağliklı bir iklim, okul etkililiği ve verimliliğinin yükseltilmesinin koşullarından biri olarak görülür. Hoy ve Miskel'e (2010) göre örgüt iklimi 6 boyutta incelenebilir ve her bir boyutta aşağıdaki özellikler görülür;

Destekleyici müdür davranışı: Öğretmenler için temel bir ilgiyi yansıtmaktadır. Okul müdürü öğretmenleri dinler ve önerilere açıtır. Öğretmenlere gerçekçi ve sık övgüde bulunulur, eleştirileri yapıcıdır.

Emredici müdür davranışı: Okul müdürü otokratik davranışlar sergiler. Katı ve sıkı bir gözetim vardır. Bu tür davranışta müdür, en küçük detaylara kadar bütün öğretmen ve okul etkinliklerini yakından ve sürekli takip etmektedir.

Kısıtlayıcı müdür davranışı: Müdür öğretmenin işine yardımcı olmaktan daha çok engel olmaktadır. Öğretmenlere gereksiz kırtasiye işleri, komite gereklilikleri, rutin görevler ve yoğun işler yüklemektedir.

Meslektaşlar arası işbirlikçi öğretmen davranışı: Öğretmenler, kendi aralarındaki mesleki davranışları desteklerler. Öğretmenler hırslı, kabul edici, birbirlerine yardımcı ve meslektaşlarının profesyonel yeterliliğine saygılıdır.

Samimi öğretmen davranışı: Okul içerisindeki güçlü ve yakın sosyal destek ağını yansıtmaktadır. Öğretmenler birbirlerini çok iyi tanımakta, yakın arkadaşlıklar kurmakta ve sik s1k bir araya gelmektedir.

Umursamaz ögretmen davranışı: Anlama ve profesyonel etkinliklere odaklanma eksikliğini yansıtmaktadır. Öğretmenler, sadece zaman doldurmaktadır. Davranışları olumsuzdur ve meslektaşlarını eleştirirler.

Örgüt ikimi kurum çalışanlarının davranışlarını etkiler. Örgüt iklimi hem liderlik tarzı, örgüt yapısı gibi örgüt özelliklerinden etkilenen hem de kişilerin iş davranışlarını ve işe dayalı tutumlarını etkileyen aracı bir değişken olarak ele alınmalıdır (Önen, 2008). Olumlu bir okul ikliminde akademik gelişime ve öğrenmeye önem verilir; öğrenciler ve öğretmenler arasında olumlu ilişkiler vardır; okul toplumunun tüm üyeleri birbirine saygı duyar; adil ve tutarlı bir disiplin politikası izlenir; aile desteği ve katılımı önemsenir. Bu nedenle, öğrencilerin okula bağlılık göstermesi, okul iklimi ve okuldan memnuniyet ile ilişkilidir (Özdemir, Sezgin, Şirin, Karip ve Erkan, 2010).

Okulun amaçlarını gerçekleştirecek ve okulun iklimini muhafaza edecek kişi ise okul müdürü olmalıdır (Bursalıoğlu, 2011). Okulun lideri olarak okul müdürün rolü okul iklimi üzerinde derin bir etkiye sahiptir (Pepper ve Thomas, 2002). Okul yöneticisi olumlu okul iklimi oluşturmak için liderlik becerilerini kullanarak etik kurallara uymalı, çalışanlarına rehberlik yaparak mesleki yardımda bulunmalı, yapılacak çalışmaları planlayarak gereken kaynağı sağlamalı, ilgilileri karar sürecine katarak güdülemeli, öğretmen ve öğrencilerle işbirliği yaparak iyi ilişkiler kurmalıdır (Taymaz, 2007). Okul müdürünün liderlik özelliklerine sahip olması bu durumu kolaylaştıracaktır. Çünkü bir lider, hem kişisel hem de mesleki olarak ne yapmak istediğini bilirse engellere rağmen amacına ulaşabilecek gücü kendinde bulacaktır (Bennis, 2003). 
Dönüşümcü liderlik, örgütte etkili değişimi gerçekleştirmeye yönelik liderlik biçimidir. Bu liderlik biçiminde örgütün iç çevresinin denetim ve eşgüdümüne dayalı bir liderlik anlayışından çok öğrenmeyi kolaylaştırıcı ve yenilikçi bir liderliğe ihtiyaç duyulmaktadır (Çelik, 2003). Dönüşümcü lider; izleyicilerin güdülenmelerini ve üst düzey performans göstermelerini sağlayan kişidir (Hellriegel, Slocum ve Woodman, 1995). Dönüşümcü liderlik süreci, hem liderin hem de izleyenlerin kendilerini bireysel olarak geliştirmelerini ve örgütsel gelişmeye katkıda bulunmalarını sağlamaktadır. İzleyenlere liderlik yeteneği kazandırırken, lidere daha üst düzeyde bir liderlik yeteneği kazandırmaktadır (Aydın, 2010).

Dönüşümcü liderlik konusundaki araştırmalar incelendiğinde; dönüşümcü liderliğin okul performansı üzerinde etkisinin olduğu (Marks ve Printy, 2003); toplam kalite yönetimi ile dönüşümcü liderlik arasında anlamlı ilişki olduğu (Serinkan, 2003); dönüşümcü liderlik özellikleri ile iş doyumu arasında ilişki olduğu (Bilir, 2007); dönüşümcü ve etkileşimci liderlik davranışlarının örgütsel bağl1lığa etkisinin olduğu (Yavuz, 2008); örgütsel gelişmenin sağlanmasında dönüşümcü liderlerin rolünün olduğu (Şahin, 2009); kriz yönetimi ve dönüşümcü liderlik arasında anlamlı bir ilişki olduğu (Ulutaş, 2010); okul yöneticilerinin özbilinç yeterliliği ve dönüşümcü liderlik özellikleri arasında anlamlı ilişki olduğu (Çelik, 2010) sonuçlarına ulaşılmıştır.

Dönüşümcü liderliğin temel amacı, örgütsel dönüşümü gerçekleştirmektir. Dönüşümcü liderlikte çok hızlı değişen çevreye uyum sağlamak büyük önem taşımaktadır. Değişim hızının yoğun bir şekilde yaşandığı günümüzde eski liderlik davranışlarıyla değişim sürecine uyum sağlayabilmek mümkün değildir. Buna en çok dönüşümcü liderlerin uyum sağlayabileceği öne sürülmektedir. Dönüşümcü liderlik, örgütte ani ve etkili değişimi geliştirmeye yönelik bir liderlik biçimidir (Çelik, 2003).

Dönüşümcü liderin temel davranış yönelimi, dönüşüm ve paylaşılan vizyonun oluşturulmasıdır. Dönüşümcü liderlik, eğitimde örgütsel yenileşme açısından kritik bir liderlik biçimi olarak görülmektedir. Dönüşümcü lider, öğretmenleri entelektüel açıdan özendiren, onlara dönüşümün ruh ve heyecanını aş1layan liderdir. Bu yönüyle eğitimde temel dönüşümler gerçekleştiren liderlerin bir yönüyle ilham kaynağı olması ve karizmatik bazı davranışlar göstermesi gerekir (Çelik, 2003). Karizma kişiye özgü bir niteliktir. Özel özellikler, lideri sıradan yönetmenden ayırır. Lider, bu özellikleriyle astlarından sevgi ve saygı görür, kimi kez astlar bu özellikleri kazanmak için liderlerle özdeşleşirler. Liderin, esin kaynağı olması, astlarının duygularını yükseltir, onlara yaşam sevinci, canlılık verir. Esin verme yeterliği, dönüşümcü önderin özelliğindendir ve astlarını örgütsel amaçlara güdülemenin kaynağıdır (Başaran, 2000).

Dönüşümcü liderliğin temel boyutlarının; karizma veya idealleştirilmiş etki, esinlenmiş motivasyon, entelektüel uyarım ve bireysel ilgi olduğu görülmektedir:

İdealleştirilmiş Etki: Liderin etkisi, özellikleri ve davranışları izleyenleri tarafından idealleştirilmiştir. $\mathrm{Bu}$ nedenle idealleştirilmiş etki davranış olarak idealleştirilmiş etki ve atfedilen idealleştirilmiş etki olarak iki ayrı alt boyutta ele alınabilir. Davranış alt boyutu liderin kendisi için önemli değer ve inançlar hakkında konuşması, bir amaç duygusuna sahip olmanın önemini vurgulaması, kararların ahlaki 
ve etik sonuçlarını dikkate alması ve ortak bir misyon duygusuna sahip olmanın önemini vurgulaması gibi davranışları içerir. Lidere atfedilen etkiler ise liderin astların kendisi ile çalışmaktan gurur duymalarını sağlaması, grubun yararına olacak şeyleri kendi çıkarlarından üstün tutması, izleyenlerin saygı duymasını sağlaması ve kendine güvenen, güçlü biri olduğu izlenimi vermesi gibi lidere atfedilen etkileri içerir (Karip, 1998).

Esinlenmiş Motivasyon: Lider anlamlardan esinlenir ve anlamayı kolaylaştıracak basit semboller kullanır. Lider izleyenler için iyimser bir hava oluşturur ve izleyenlerde heyecan uyandırır. İzleyenler için yüksek beklentiler oluşturur ve izleyenleri, ortak amacın bir parçası olmaları için güdüler (Altun, 2003).

Entelektüel Uyarım: Lider astlarını işlerin şu anki yapılış biçimlerini, işlemleri, eylemleri, kendi düşünce ve değerlerini, kurumun ve liderin düşünmesini yönlendiren değerleri sorgulamaya teşvik eder. Lider, güçlüklerle ve engellerle baş edebilmek için astların alışılagelmiş davranış ve düşünüş kalıplarını sorgulamalarını ve daha önceden de var olan problemler hakkında yeni bakış açıları oluşturmalarını sağlar. Böylece lider örgütün entelektüel, yenilikçi ve daha iyi için değişimci kapasitesini atıl kalmaktan kurtararak aktif konuma getirir (Karip, 1998).

Bireysel Illgi: Lider her izleyenin bireysel ihtiyaçlarına duyarlıdır ve bireysel farklılıkları kabul eder. İzleyenler için öğrenme firsatları oluşturur. Lider, izleyenleri çift yönlü iletişim kurmaları yönünde cesaretlendirir (Altun, 2003).

Etkili okul konusunda yapılan araştırmalarda, okul yöneticilerinin liderlik davranışları ile birlikte üzerinde en çok durulan boyutlardan biri de okul iklimi ve ortamıdır. Bir okulun etkili olabilmesi için öğrenmeyi ve öğretmeyi teşvik eden sosyal bir ortam hazırlanmalıdır. Bu konuda en etkili belirleyici ise okul yöneticisi olmaktadır (Şişman, 2012). Her şeyden önce liderlik insana ve insanlar arası etkin iletişime dair bir meseledir (Adair ve Reed, 2008).

Pepper ve Thomas (2002), okul iklimi üzerindeki liderlik rolünün etkileri üzerine yaptıkları araştırmada; dönüşümcü liderliğin öğrenme ve çalışma ortamı ile ilgili olumlu etkisi olduğu sonucuna varmıştır. Moolenaar, Daly ve Sleegers (2010), dönüşümcü liderlik sosyal ağ ve okulun yenilikçi iklimi arasındaki ilişkinin incelenmesi konusunda yaptıkları araştırmada; dönüşümcü liderlik okullarda yenilikler geliştirmek ve uygulamak için, artan taleplere yanıt vermede umut verici bir liderlik olarak görülmektedir. Ayrıca dönüşümcü liderlik olumlu bir okul iklimi oluşturmada etkilidir. Emeksiz (2003), okul iklimi ve liderlik üzerine yaptığı araştırmada, ilköğretim okulu sınıf ve branş öğretmenlerinin "okul iklimi ve liderliğe" ilişkin görüşlerini incelemiş, okul iklimi ve liderlik arasında yüksek düzeyde ilişki olduğu sonucu ortaya çıkmıştır. Holloway (2012), liderlik ve örgüt iklimi üzerine yaptığı araştırmada, belli liderlik davranışları ile örgütsel iklimin boyutları arasında ilişki olduğu sonucuna varmıştır.

Dönüşümcü liderlik davranışları ile okul iklimi arasındaki ilişkinin belirlenmesi, okul yöneticilerinin olumlu bir iklim için liderlik davranışları sergilemeleri açısından önemli olduğu düşünülmektedir. Dönüşümcü liderlik davranışları sergileyen okul yöneticileri okul içinde olumlu bir hava oluşturarak okul amaçlarının etkili bir biçimde 
gerçekleştirilmesini sağlayabilir. Olumlu bir iklim oluşturmak için dönüşümcü liderlik davranışlarının önemli olduğu düşünüldüğünde, araştırmanın sonuçlarının literatüre anlamlı bir katkıda bulunması beklenmektedir.

$\mathrm{Bu}$ araştırma ile ilköğretim kurumlarında görev yapan öğretmenlerin örgütsel iklim ile dönüşümcü liderlik algıları arasındaki ilişkinin belirlenmesi amaçlanmıştır. Bu amaç çerçevesinde aşağıdaki sorulara cevap aranmıştır:

1. İlköğretim Okulu öğretmenleri örgütsel iklimi ve okul yöneticilerinin dönüşümcü liderlik davranışlarını ne düzeyde algılamaktadırlar?

2. İlköğretim Okulu öğretmenlerinin algılarına göre, örgütsel iklim ile dönüşümcü liderlik arasında anlamlı ilişki var mıdır?

3. İlköğretim Okulu öğretmenlerinin algılarına göre, okul yöneticilerinin dönüşümcü liderlik davranışları örgütsel iklimi anlamlı düzeyde yordamakta mıdır?

\section{Yöntem}

\section{Model}

Tarama modelinde olan bu çalışmada, ilköğretim okulu öğretmenlerinin algılarına göre, örgütsel iklim ile dönüşümcü liderlik arasındaki ilişkiler incelenmiştir. Araştırmanın bağımlı değişkenlerini örgüt iklimini destekleyici müdür davranışı, emredici müdür davranışı, kısıtlayıcı müdür davranışı, samimi öğretmen davranış1, işbirlikçi öğretmen davranışı ve umursamaz öğretmen davranışı boyutları oluşturmaktadır. Bağımsız değişkenler ise, dönüşümcü liderliğin; ideal etki, entelektüel uyarım, esin kaynağı olma ve bireyselleştirilmiş ilgi boyutlarıdır. Bununla birlikte, mevcut araştırma bulguları bağımlı ve bağımsız değişkenler arasında neden-sonuç ilişsisi kurmak için yeterli görülmediğinden, araştırmada değişkenler arasındaki ilişkiler ve bağımsız değişkenlerin yordayıcılık düzeyleri incelenmiştir.

\section{Evren ve Örneklem}

Araştırmanın evrenini 2012- 2013 eğitim öğretim yılında Erzurum ili Yakutiye ilçe merkezinde Milli Eğitim Bakanlığı'na bağlı devlet ilköğretim okullarında görev yapmakta olan 1100 öğretmen oluşturmaktadır. Araştırmanın örneklemi, basit tesadüfi yöntem ile belirlenen 15 ilköğretim okulunda görev yapan 258 ilköğretim okulu öğretmenidir. Bu katılımcıların 140’1 (\%54.3) kadın ve 118' i (\%45.7) erkektir. Araştırmaya katılan ilköğretim okulu öğretmenlerin mesleki kıdeme göre dağılımı incelendiğinde, 46's1 (\%17.8) 1-5 y11, 56's1 (\%21.7) 6-10 y11, 80’i (\%31) 11-15 y1l, 51'i (\%19.8) 16-20 y1l, 25'i (\%9.7) 21 yıl ve üzeri mesleki kıdeme sahip oldukları görülmektedir.

\section{Veri Toplama Araçları}

Araştırmanın veri toplama aracı üç bölümden oluşmaktadır. Birinci bölümde, araştırmaya katılan öğretmenlerin cinsiyet, branş ve mesleki kıdem gibi demografik bilgileri yer almaktadır. İkinci bölümde ise, 37 maddeden ve 4 alt boyuttan oluşan 
Dönüşümcü Liderlik Anketi, üçüncü bölümde 39 madde, 6 alt boyuttan oluşan Örgüt İklimi Ölçeği yer almaktadır.

Dönüşümcü liderlik anketi. Dönüşümcü liderliğin ölçümünde, Avolio ve Bass'ın (1995) geliştirdiği ve Çelik (2010) tarafından kullanılan, Dönüşümcü Liderlik Anketi (Transformational Leadership Questionnaire-TLQ) kullanılmıştır. Dönüşümcü Liderlik Anketi, 4 alt boyut ve 37 maddeden oluşmaktadır. Ankette yer alan maddeler; "Her Zaman" (5), "Çoğunlukla" (4), "Bazen" (3), "Nadiren” (2) ve "Hiçbir Zaman" (1) seçeneklerinden oluşan 5'li likert derecelendirme ölçeğine göre hazırlanmıştır. Dönüşümcü Liderlik Anketi için Çelik'in (2010) yaptığı güvenirlik analizi sonucunda elde edilen Croanbach Alpha iç tutarlılık katsayısı "İdeal Etki" için .88, "Entelektüel Uyarım" için .89, "Esin Kaynağı Olma" için .92, "Bireyselleştirilmiş İlgi” için .92, anketin tamamı için ise .92 olarak bulunmuştur. Bu araştırmada yapılan istatistik analiz sonuçlarına göre ölçeğin toplam Cronbach Alpha iç tutarlık katsayısı .97'dir. Alt boyutların Cronbach Alfa iç tutarlılık katsayısı ise, "İdeal Etki" .93; "Entelektüel Uyarım" .89; "Esin Kaynağı Olma" .94 ve "Bireyselleştirilmiş İlgi" .93 olarak bulunmuştur.

Örgüt iklimi ölçeği. Öğretmenlerin okul iklimine ilişkin algılarını belirlemek için Steve Hoy ve Tarter (1997) tarafindan geliştirilmiş ve Yılmaz ve Altınkurt (2013) tarafından Türkçeye uyarlaması yapılmıştır. Ölçek, destekleyici müdür davranışı, emredici müdür davranışı, kısıtlayıcı müdür davranışı, samimi öğretmen davranışı, işbirlikçi öğretmen davranışı ve umursamaz öğretmen davranışı olmak üzere 6 boyut ve 39 maddeden oluşmaktadır. Altı faktörünün birlikte açıkladığı varyans oranı ise \% 51'dir. Ölçek dörtlü likert tipindedir. Her madde "Nadiren Olur”, "Bazen Olur”, "Genellikle Olur" ve "Çok Sık Olur" şeklinde 4 düzeyde derecelendirilmiştir. Ölçeğin Cronbach Alpha iç tutarlılık katsayısı; "Destekleyici Müdür Davranışı” faktörü için .89, "Emredici Müdür Davranışı" faktörü için .78; "Kısıtlayıcı Müdür Davranışı" faktörü için .73; "Samimi Öğretmen Davranışı" faktörü için .82, "Meslektaşlar Arasında İşbirlikçi Öğretmen Davranışı" faktörü için .80 ve "Umursamaz Öğretmen Davranışı" faktörü için .70 olarak bulunmuştur. Bu araştırmada yapılan istatistik analiz sonuçlarına göre ölçeğin toplam güvenirliği .87'dir. Alt boyutların Cronbach's Alfa iç tutarlılık katsayıs1; "Destekleyici Müdür Davranışı" boyutu için .89; "Emredici Müdür Davranışı" boyutu için .85; "Kısıtlayııı Müdür Davranışı" boyutu için .53; "Samimi Öğretmen Davranışı” boyutu için .90; "Meslektaşlar Arasında İşbirlikçi Öğretmen Davranışı" boyutu için .75 ve "Umursamaz Öğretmen Davranışı" boyutu için .75 olarak bulunmuştur.

\section{Verilerin Analizi}

Araştırmada alt problemlerin çözümlenebilmesi için öncelikle her bir alt ölçekte yer alan maddelerin aritmetik ortalama değerleri belirlenerek her faktör için bir puan hesaplanmıştır. Analizler bu faktör puanları üzerinden yapılmıştır. Değişkenler arasındaki ilişkilerin hesaplanmasında Pearson Momentler Çarpım Korelasyon 
Katsayısı $(r)$ kullanılmıştır. Bununla birlikte, bağımsız değişkenlerin bağımlı değişkenleri yordama düzeylerini belirlemek amaciyla Çoklu Doğrusal Regresyon Analizi yapılmıştır. Regresyon analizlerinin yorumlanmasında, standartlaştırılmış Beta ( $\beta)$ katsayıları ve bunların anlamlılığına ilişin t-testi sonuçları dikkate alınmıştır. Verilerin analizinde .05 anlamlılık düzeyi esas alınmıştır.

\section{Bulgular}

\section{Örgütsel İklim ve Okul Yöneticilerinin Dönüşümcü Liderlik Davranışları}

Araştırmaya katılanların okul müdürlerinin dönüşümcü liderlik davranışları ve örgüt iklimine yönelik algı düzeylerine ilişkin bulgular Tablo 1'de yer almaktadır.

Tablo 1

Dönüşümcü Liderlik ve Örgütsel İklim Boyutlarına İlişkin Aritmetik Ortalama ile Standart Sapma Değerleri

\begin{tabular}{lcc}
\hline Alt Boyutlar & $\bar{X}$ & $s s$ \\
\hline 1. İdealleştirilmiş etki & 3.29 & .850 \\
2. Entelektüel uyarım & 3.17 & .828 \\
3. Esin kaynağı olma & 3.11 & .830 \\
4. Bireyselleştirilmiş ilgi & 3.35 & .925 \\
5. Destekleyici Müdür Davranışları & 2.80 & .678 \\
6. Emredici Müdür Davranışları & 2.31 & .734 \\
7. Kısıtlayıcı Müdür Davranışları & 2.72 & .634 \\
8. Samimi Öğretmen Davranışları & 2.92 & .709 \\
9. İşbirlikçi Öğretmen Davranışları & 3.02 & .542 \\
10. Umursamaz Öğretmen Davranışları & & .746 \\
11. Dönüşümcü liderlik (Toplam) & 2.03 & .799 \\
12. Okul İklimi (Toplam) & 3.23 & .390 \\
\hline
\end{tabular}

Çalışma grubundaki öğretmenlerin algılarına göre okul müdürlerinin dönüşümcü liderlik davranışları ile örgütsel iklime ilişkin dağılımlar incelendiğinde; dönüşümcü liderlik boyutları açısından en yüksek puan ortalaması, Bireyselleştirilmiş ilgi boyutunda $(\bar{x}=3.35)$ olurken, en düşük puan ortalamasının esin kaynağı olma boyutunda ( $\bar{x}=3.11)$ olduğu görülmektedir. Dönüşümcü liderlik davranışlarına yönelik diğer dağılımlara bakıldığında ise, idealleştirilmiş etki ( $\bar{x}=3.29)$ boyutunu entelektüel uyarım ( $\bar{x}=3.49)$ boyutunun izlediği görülmektedir. Örgütsel iklime ilişkin dağılımlara bakıldığında ise, en yüksek puan işbirlikçi öğretmen davranışları boyutunda ( $\bar{x}=3.02)$ olurken, en düşük puan ortalamasının umursamaz öğretmen davranışları boyutunda $(\bar{x}=2,03)$ olduğu görülmektedir. Örgüt iklimine yönelik diğer dağılımlara bakıldığında 
ise, destekleyici müdür davranışları boyutunda $(\bar{x}=2.80)$, emredici müdür davranışları boyutunda ( $\bar{x}=2.31)$, kısıtlayıcı müdür davranışları boyutunda $(\bar{x}=2.72)$, samimi öğretmen davranışları boyutunda $(\bar{x}=2.92)$ olduğu görülmektedir.

\section{Örgütsel İklim İle Dönüşümcü Liderlik Arasındaki İlişki}

Okul müdürlerinin dönüşümcü liderlik davranışları ile örgütsel iklim arasındaki ilişkiyi belirlemek için Pearson momentler çarpımı korelasyonu tekniği uygulanmış ve sonuçlar Tablo 2'de verilmiştir.

Korelasyon katsayısının 1.00 olması mükemmel pozitif bir ilişkiyi; -1.00 olması mükemmel negatif bir ilişkiyi; 0.00 olması ilişkinin olmadığını gösterir. Korelasyon katsayısının mutlak değer olarak 0.70-1.00 arasında olması yüksek, 0.70-0.30 arasında olması orta, 0.30-0.00 arasında olması ise düşük düzeyde bir ilişki olarak tanımlanabilir (Büyüköztürk, 2007).

Tablo 2

Okul Müdürlerinin Dönüşümcü Liderlik Davranışları İle Örgütsel İklim Arasındaki Korelasyonlar

\begin{tabular}{|c|c|c|c|c|c|c|c|c|c|c|c|}
\hline Alt boyutlar & 1 & 2 & 3 & 4 & 5 & 6 & 7 & 8 & 9 & 10 & 11 \\
\hline 1. İdealleştirilmiş etki & - & & & & & & & & & & \\
\hline 2. Entelektüel uyarım & $.79^{* *}$ & - & & & & & & & & & \\
\hline 3. Esin kaynağı olma & $.80^{* *}$ & $.84^{* *}$ & - & & & & & & & & \\
\hline $\begin{array}{l}\text { 4. Bireyselleştirilmiş } \\
\text { ilgi }\end{array}$ & $.82^{* *}$ & $.78^{* *}$ & $.84^{* *}$ & - & & & & & & & \\
\hline $\begin{array}{l}\text { 5. Destekleyici Müdür } \\
\text { Dav. }\end{array}$ & $.77^{* *}$ & $.67^{* *}$ & $.74^{* *}$ & $.75^{* *}$ & - & & & & & & \\
\hline $\begin{array}{l}\text { 6. Emredici Müdür } \\
\text { Davranışları }\end{array}$ & $.22^{* *}$ & $.30^{* *}$ & $.32^{* *}$ & $.24^{* *}$ & $.25^{* *}$ & - & & & & & \\
\hline $\begin{array}{l}\text { 7. Kısıtlayıcı Müdür } \\
\text { Dav. }\end{array}$ & -.06 & .03 & -.01 & -.09 & -.03 & $.26^{* *}$ & - & & & & \\
\hline $\begin{array}{l}\text { 8. Samimi Öğretmen } \\
\text { Dav. }\end{array}$ & $.31^{* *}$ & $.32^{* *}$ & $.33^{* *}$ & $.30^{* *}$ & $.33^{* *}$ & $.33^{* *}$ & .12 & - & & & \\
\hline $\begin{array}{l}\text { 9. İşbirlikçi Öğretmen } \\
\text { Dav. }\end{array}$ & $.42^{* *}$ & $.48^{* *}$ & $.44^{* *}$ & $.41^{* *}$ & $.50^{* *}$ & $.32^{* *}$ & .08 & $.65^{* *}$ & - & & \\
\hline $\begin{array}{l}\text { 10. Umursamaz } \\
\text { Öğretmen Dav. }\end{array}$ & $-.14^{*}$ & -.04 & .00 & $-15^{*}$ & -.11 & $.23^{* *}$ & $.48^{* *}$ & -.03 & $-13^{*}$ & - & \\
\hline $\begin{array}{l}\text { 11. Dönüşümcü } \\
\text { liderlik (Toplam) }\end{array}$ & $.92^{* *}$ & $.91^{* *}$ & $.94^{* *}$ & $.94^{* *}$ & $.79^{* *}$ & $.29^{* *}$ & -.05 & $.34^{* *}$ & $.47^{* *}$ & -.09 & - \\
\hline $\begin{array}{l}\text { 12. Örgüt İklimi } \\
\text { (Toplam) }\end{array}$ & $.52^{* *}$ & $.56^{* *}$ & $.58^{* *}$ & $.50^{* *}$ & $.65^{* *}$ & $.69^{* *}$ & $.44^{* *}$ & $.71^{* *}$ & $.72^{* *}$ & $.28^{* *}$ & $.58^{* *}$ \\
\hline
\end{tabular}
$\eta=258,{ }^{*} \mathrm{p}<.05, * * \mathrm{p}<.01$ 
Tablo 2 incelendiğinde araştırmaya katılan öğretmenlerin dönüşümcü liderlik ve okul iklime ilişkin algıları arasında anlamlı ilişkilerin olduğu görülmektedir.

Dönüşümcü liderlik anketinin idealleştirilmiş etki boyutu ile örgüt iklimin destekleyici müdür davranışları $(\mathrm{r}=.76, \mathrm{p}<.01)$, emredici müdür davranışları $(r=.21$, $\mathrm{p}<.01)$, samimi öğretmen davranışları $(\mathrm{r}=.31, \mathrm{p}<.01)$ ve işbirlikçi öğretmen davranışları $(\mathrm{r}=.39, \mathrm{p}<.01)$ boyutları arasında pozitif yönde anlamlı ilişkilerin olduğu görülürken; kısıtlayıcı müdür davranışları $(r=-.17, p<.01)$ ve umursamaz öğretmen davranışları $(r=-$ $.13, \mathrm{p}<.05)$ boyutları arasında negatif yönde anlamlı ilişkinin olduğu görülmektedir.

Bunun yanında dönüşümcü liderliğin entelektüel uyarım boyutu ile örgüt iklimin destekleyici müdür davranışları $(\mathrm{r}=.67, \mathrm{p}<.01)$, emredici müdür davranışları $(\mathrm{r}=.30, \mathrm{p}<.01)$, samimi öğretmen davranışları $(\mathrm{r}=.32, \mathrm{p}<.01)$ ve işbirlikçi öğretmen davranışları $(\mathrm{r}=.41, \mathrm{p}<.01)$ boyutları arasında pozitif yönde anlamlı ilişki olduğu bulgulanmıştır.

Ayrıca, dönüşümcü liderliğin esin kaynağı olma boyutu ile örgüt ikliminin destekleyici müdür davranışları $(\mathrm{r}=.73, \mathrm{p}<.01)$, emredici müdür davranışları $(\mathrm{r}=.31$, $\mathrm{p}<.01)$, samimi öğretmen davranışları $(\mathrm{r}=.32, \mathrm{p}<.01)$ ve işbirlikçi öğretmen davranışları $(\mathrm{r}=.35, \mathrm{p}<.01)$ boyutları arasında pozitif yönde anlamlı bir ilişki bulunurken; kısıtlayıcı müdür davranışları $(r=-.14, p<.05)$ boyutu ile negatif yönde anlamlı ilişkinin olduğu görülmektir.

Dönüşümcü liderliğin bireyselleştirilmiş ilgi boyutu ile örgüt ikliminin destekleyici müdür davranışları $(\mathrm{r}=.74, \mathrm{p}<.01)$, emredici müdür davranışları $(\mathrm{r}=.23$, $\mathrm{p}<.05)$, samimi öğretmen davranışları $(\mathrm{r}=.30, \mathrm{p}<.01)$ ve işbirlikçi öğretmen davranışları $(\mathrm{r}=.37, \mathrm{p}<.01)$ boyutları arasında pozitif yönde, anlamlı bir ilişki bulunmuştur. Bunun yanında esin kaynağı olma boyutu ve bireyselleştirilmiş ilgi boyutu ile örgütsel ikliminin kısıtlayıcı müdür davranışları $(r=-.16, p<.01)$ ve umursamaz öğretmen davranışları $(\mathrm{r}=-.15, \mathrm{p}<.05)$ boyutları arasında negatif yönde, düşük düzeyde anlamlı bir ilişki bulunmuştur.

Araştırmaya katılan öğretmenlerin dönüşümcü liderlik ve örgüt iklimi algılarına ilişkin toplam puanları arasında $(\mathrm{r}=.57, \mathrm{p}<.01)$ pozitif yönde, orta düzeyde anlamlı bir ilişki bulunmuştur.

\section{Okul Yöneticilerinin Dönüşümcü Liderlik Davranışlarının Örgütsel İklimi Yordama Düzeyi}

Araştırmada, örgüt ikliminin yordanması amacıyla dönüşümcü liderlik anketinin boyutları ile örgüt iklimi arasında çoklu regresyon analizi yapılarak, sonuçlar Tablo 3, Tablo 4 Tablo 5, Tablo 6 , Tablo 7 ve Tablo 8'de verilmiştir.

Destekleyici müdür davranışlarının yordanması. Destekleyici müdür davranışlarının yordanmasına ilişkin çoklu doğrusal regresyon analizi sonuçları Tablo 3 'te verilmiştir. 
Tablo 3

Destekleyici Müdür Davranışlarının Yordanmasına İlişkin Regresyon Analizi Sonuçları

\begin{tabular}{lccccc}
\hline Değişken & $B$ & $s h$ & $\beta$ & $t$ & $p$ \\
\hline Sabit & .634 & .107 & - & 5.914 & .000 \\
İdealleştirilmiş etki & .328 & .058 & .410 & 5.618 & $.000^{*}$ \\
Entelektüel uyarım & -.048 & .061 & -.059 & -.787 & .432 \\
Esin kaynağı olma & .212 & .068 & .259 & 3.122 & $.002^{*}$ \\
Bireyselleştirilmiş ilgi & .176 & .057 & .240 & 3.080 & $.002^{*}$ \\
\hline \multicolumn{1}{c}{$\mathrm{F}=115.224, \mathrm{p}<.05$} & $\mathrm{R}=.803, \mathrm{R}^{2}=.646$ & & &
\end{tabular}

Tablo 3'te görüldüğü gibi, dönüşümcü liderliğin, idealleştirilmiş etki, esin kaynağı olma ve bireyselleştirilmiş ilgi boyutlarının birlikte, örgüt iklimi ölçeğinin destekleyici müdür davranışları boyutunu yordama gücü istatistiksel olarak anlamlı bulunmuştur $(\mathrm{F}=115.224, \mathrm{p}<.05)$. Dönüşümcü liderliğin tüm boyutları birlikte, öğretmenlerin destekleyici müdür davranışları algılarındaki toplam varyansın yaklaşık $\%$ 65'ini açıklamaktadır. Dönüşümcü liderliğin idealleştirilmiş etki $(\beta=.410, p<.05)$, esin kaynağı olma $(\beta=.259, \mathrm{p}<.05)$ ve bireyselleştirilmiş ilgi $(\beta=.240, p<.05)$ boyutları öğretmenlerin destekleyici müdür davranışları algılarını pozitif yönde ve anlamlı düzeyde yordamaktadır. Entelektüel uyarım ( $\beta=-.059, \quad \mathrm{p}>.05)$ destekleyici müdür davranışlarının anlamlı yordayıcısı değildir. Standardize edilmiş regresyon katsayısına göre $(\beta)$ yordayıcı değişkenlerin destekleyici müdür davranışları üzerindeki göreli önem sırası; idealleştirilmiş etki, esin kaynağı olma ve bireyselleştirilmiş ilgi olduğu görülmektedir. Regrasyon katsayılarının anlamlılığına ilişkin t-testi sonuçları incelendiğinde destekleyici müdür davranışlarını, idealleştirilmiş etki, esin kaynağı olma ve bireyselleştirilmiş ilgi boyutları değişkenlerinin anlamlı düzeyde yordadığı söylenebilir.

Emredici müdür davranışlarının yordanması. Emredici müdür davranışlarının yordanmasına ilişkin çoklu doğrusal regresyon analizi sonuçları Tablo 4 'te verilmiştir.

Tablo 4'te görüldüğü gibi, dönüşümcü liderliğin, esin kaynağı olma boyutunun birlikte, örgüt iklimi ölçeğinin emredici müdür davranışları boyutunu yordama gücü istatistiksel olarak anlamlı bulunmuştur $(\mathrm{F}=8.353, \mathrm{p}<.05)$. Dönüşümcü liderliğin tüm boyutları birlikte, öğretmenlerin emredici müdür davranışları algılarındaki toplam varyansın yaklaşık \%12'sini açıklamaktadır. Dönüşümcü liderliğin esin kaynağı olma $(\beta=.333, p<.05)$ boyutu öğretmenlerin emredici müdür davranışları algılarını pozitif yönde ve anlamlı düzeyde yordamaktadır. İdealleştirilmiş etki $(\beta=-.144, \mathrm{p}>.05)$, entelektüel uyarım $(\beta=-.195, \mathrm{p}>.05)$ ve bireyselleştirilmiş ilgi $(\beta=--.074, \mathrm{p}>.05)$ emredici müdür davranışlarının anlamlı yordayıcısı değildir. Standardize edilmiş regresyon katsayısına göre $(\beta)$ yordayıcı değişkenlerin emredici müdür davranışları 
üzerindeki göreli önem sırası; esin kaynağı olma, İdealleştirilmiş etki, entelektüel uyarım ve bireyselleştirilmiş ilgi olduğu görülmektedir. Regrasyon katsayılarının anlamlılığına ilişkin t-testi sonuçları incelendiğinde, emredici müdür davranışlarını dönüşümcü liderliğin esin kaynağı olma boyutu değişkeninin anlamlı düzeyde yordadığı söylenebilir.

Tablo 4

Emredici Müdür Davranışlarının Yordanmasına İlişkin Çoklu Regresyon Analizi Sonuçları

\begin{tabular}{lccccc}
\hline Değişken & $B$ & $s h$ & $\beta$ & $t$ & $p$ \\
\hline Sabit & 1.457 & .183 & - & 7.957 & .000 \\
İdealleştirilmiş etki & -.125 & .100 & -.144 & -1.252 & .212 \\
Entelektüel uyarım & .173 & .105 & .195 & 1.656 & .099 \\
Esin kaynağı olma & .294 & .116 & .333 & 2.541 & $.012 *$ \\
Bireyselleştirilmiş ilgi & -.059 & .097 & -.074 & -.603 & .547 \\
\hline
\end{tabular}

$\mathrm{F}=8.353, \mathrm{p}<.05 \quad \mathrm{R}=.342, \mathrm{R}^{2}=.117$

Kısıtlayıcı müdür davranışlarının yordanması. Kısıtlayıcı müdür davranışlarının yordanmasına ilişkin çoklu doğrusal regresyon analizi sonuçları Tablo 5 'te verilmiştir.

Tablo 5

Kısıtlayıcı Müdür Davranışlarının Yordanmasına İlişkin Çoklu Doğrusal Regresyon Analizi Sonuçları

\begin{tabular}{lccccc}
\hline Değişken & $B$ & $s h$ & $\beta$ & $t$ & $p$ \\
\hline Sabit & 3.115 & .164 & - & 18.942 & .000 \\
İdealleştirilmiş etki & -.154 & .089 & -.206 & -1.721 & .087 \\
Entelektüel uyarım & .181 & .094 & .236 & 1.926 & .055 \\
Esin kaynağı olma & -.083 & .104 & -.109 & -.802 & .423 \\
Bireyselleştirilmiş ilgi & -.059 & .088 & -.086 & -.670 & .503 \\
\hline \multicolumn{1}{c}{$\mathrm{F}=3.056, \mathrm{p}<.05$} & $\mathrm{R}=.215, \mathrm{R}^{2}=.046$ & & &
\end{tabular}

Tablo 5'te görüldüğü gibi, dönüşümcü liderliğin, idealleştirilmiş etki, entelektüel uyarım, esin kaynağı olma ve bireyselleştirilmiş ilgi boyutlarının birlikte, örgüt iklimi ölçeğinin kısıtlayıcı müdür davranışları boyutunu yordama gücü istatistiksel olarak pozitif yönde ve düşük düzeyde anlamlı bulunmuştur $(\mathrm{F}=3.056, \mathrm{p}<.05)$. Dönüşümcü 
liderliğin tüm boyutları birlikte, öğretmenlerin emredici müdür davranışları algılarındaki toplam varyansın yaklaşık \%5'ini açıklamaktadır. Dönüşümcü liderliğin idealleştirilmiş etki ( $\beta=-.206, p>.05)$ entelektüel uyarım $(\beta=.236, p<.05)$, esin kaynağ1 olma $(\beta=-.109, \mathrm{p}>.05)$ ve bireyselleştirilmiş ilgi $(\beta=-.086, \mathrm{p}<.05)$ boyutları kısıtlayıc1 müdür davranışlarının anlamlı yordayıcısı değildir. Standardize edilmiş regresyon katsayısına göre $(\beta)$ yordayıcı değişkenlerin kısıtlayıcı müdür davranışları üzerindeki göreli önem sırası; entelektüel uyarım, idealleştirilmiş etki, esin kaynağı olma ve bireyselleştirilmiş ilgi olduğu görülmektedir. Regresyon katsayılarının anlamlılığına ilişkin t-testi sonuçları incelendiğinde, kısıtlayıcı müdür davranışlarını dönüşümcü liderlik ölçeğinin hiçbir boyutunun anlamlı düzeyde yordamadığı söylenebilir.

Samimi öğretmen davranışlarının yordanması. Samimi öğretmen davranışlarının yordanmasına ilişkin çoklu doğrusal regresyon analizi sonuçları Tablo 6'da verilmiştir.

Tablo 6

Samimi Öğretmen Davranışlarının Yordanmasına İlişkin Çoklu Doğrusal Regresyon Analizi Sonuçları

\begin{tabular}{lccccc}
\hline Değişken & $B$ & $s h$ & $\beta$ & $t$ & $p$ \\
\hline Sabit & 1.935 & .177 & - & 10.936 & .000 \\
İdealleştirilmiş etki & .079 & .096 & .095 & .822 & .412 \\
Entelektüel uyarım & .097 & .101 & .113 & .959 & .338 \\
Esin kaynağı olma & .118 & .112 & .138 & 1.051 & .294 \\
Bireyselleştirilmiş ilgi & .015 & .094 & .020 & .163 & .870 \\
\hline
\end{tabular}

$\mathrm{F}=8.337, \mathrm{p}<.05 \quad \mathrm{R}=.341, \mathrm{R}^{2}=.116$

Tablo 6' da görüldüğü gibi, dönüşümcü liderliğin, idealleştirilmiş etki, entelektüel uyarım, esin kaynağı olma ve bireyselleştirilmiş ilgi boyutlarının birlikte, örgüt iklimi ölçeğinin samimi öğretmen davranışları boyutunu yordama gücü istatistiksel olarak pozitif yönde ve orta düzeyde anlamlı bulunmuştur $(F=8.337, p<.05)$. Dönüşümcü liderliğin tüm boyutları birlikte, öğretmenlerin emredici müdür davranışları algılarındaki toplam varyansın yaklaşık \%12'sini açıklamaktadır. Dönüşümcü liderliğin idealleştirilmiş etki $(\beta=.095, \mathrm{p}>.05)$, entelektüel uyarım $(\beta=.113, \mathrm{p}>.05)$, esin kaynağ olma $(\beta=-.138, \mathrm{p}>.05)$ ve bireyselleştirilmiş ilgi $(\beta=.020, \mathrm{p}<.05)$ boyutları, araştırmaya katılanların samimi öğretmen davranışlarının anlamlı yordayıcısı değildir. Standardize edilmiş regresyon katsayısına göre $(\beta)$ yordayıcı değişkenlerin samimi öğretmen davranışları üzerindeki göreli önem sırası; esin kaynağı olma, entelektüel uyarım, idealleştirilmiş etki ve bireyselleştirilmiş ilgi olduğu görülmektedir. Regrasyon katsayılarının anlamlılığına ilişkin t-testi sonuçları incelendiğinde, samimi öğretmen 
davranışlarını dönüşümcü liderlik ölçeğinin hiçbir boyutunun anlamlı düzeyde yordamadığı söylenebilir.

İşbirlikçi öğretmen davranışlarının yordanması. İşbirlikçi öğretmen davranışlarının yordanmasına ilişkin çoklu doğrusal regresyon analizi sonuçları Tablo 7'de verilmiştir.

Tablo 7

İşbirlikçi Öğretmen Davranışlarının Yordanmasına İlişkin Çoklu Doğrusal Regresyon Analizi Sonuçları

\begin{tabular}{lccccc}
\hline Değişken & $B$ & $s h$ & $\beta$ & $t$ & $p$ \\
\hline Sabit & 2.091 & .130 & - & 16.099 & .000 \\
İdealleştirilmiş etki & .106 & .071 & .166 & 1.496 & .136 \\
Entelektüel uyarım & .197 & .074 & .302 & 2.662 & $.008^{*}$ \\
Esin kaynağı olma & -.078 & .082 & -.120 & -.955 & .341 \\
Bireyselleştirilmiş ilgi & .061 & .069 & .104 & .879 & .380 \\
\hline
\end{tabular}

$$
\mathrm{F}=14.471, \mathrm{p}<.05 \quad \mathrm{R}=.431, \mathrm{R}^{2}=.186
$$

Tablo 7'de görüldüğü gibi, dönüşümcü liderliğin, idealleştirilmiş etki, entelektüel uyarım, esin kaynağı olma ve bireyselleştirilmiş ilgi boyutlarının birlikte, örgüt iklimi ölçeğinin öğretmenlerin işbirlikçi öğretmen davranışları boyutunu yordama gücü istatistiksel olarak pozitif yönde ve orta düzeyde anlamlı bulunmuştur ( $F=14.471$, $\mathrm{p}<.05)$. Dönüşümcü liderliğin tüm boyutları birlikte, öğretmenlerin işbirlikçi öğretmen davranışları algılarındaki toplam varyansın yaklaşık \%19'unu açıklamaktadır. Dönüşümcü liderliğin entelektüel uyarım $(\beta=.302, p<.01)$ boyutu, öğretmenlerin işbirlikçi öğretmen davranışları algılarını pozitif yönde ve anlamlı düzeyde yordamaktadır. İdealleştirilmiş etki $(\beta=.166, p>.05)$ ve esin kaynağı olma $(\beta=-.120$, $\mathrm{p}>.05)$ ve bireyselleştirilmiş ilgi $(\beta=.104, p>.05)$ boyutları işbirlikçi öğretmen davranışlarının anlamlı yordayıcısı değildir. Standardize edilmiş regresyon katsayısına göre $(\beta)$ yordayıcı değişkenlerin işbirlikçi öğretmen davranışlarının üzerindeki göreli önem sırası; entelektüel uyarım, idealleştirilmiş etki, esin kaynağı olma ve bireyselleştirilmiş ilgi olduğu görülmektedir. Regrasyon katsayılarının anlamlılığına ilişkin t-testi sonuçları incelendiğinde, işbirlikçi öğretmen davranışlarını dönüşümcü liderlik ölçeğinin entelektüel uyarım değişkeninin anlamlı düzeyde yordadı̆̆ söylenebilir.

Umursamaz öğretmen davranışlarının yordanması. Umursamaz öğretmen davranışlarının yordanmasına ilişkin çoklu doğrusal regresyon analizi sonuçları Tablo 8 'de verilmiştir. 
Tablo 8

Umursamaz Öğretmen Davranışlarının Yordanmasına İlişkin Çoklu Doğrusal Regresyon Analizi Sonuçları

\begin{tabular}{lccccc}
\hline Değişken & $B$ & $s h$ & $\beta$ & $t$ & $p$ \\
\hline Sabit & 2.304 & .189 & - & 12.215 & .000 \\
İdealleştirilmiş etki & -.193 & .103 & -.220 & -1.878 & .062 \\
Entelektüel uyarım & .045 & .108 & .050 & .417 & .677 \\
Esin kaynağı olma & .435 & .119 & .484 & 3.645 & $.000^{*}$ \\
Bireyselleştirilmiş ilgi & -.337 & .100 & -.418 & -3.355 & $.001^{*}$ \\
\hline \multicolumn{1}{c}{$\mathrm{F}=6.398, \mathrm{p}<.01$} & $\mathrm{R}=.303, \mathrm{R}^{2}=.092$ & & &
\end{tabular}

Tablo 8'de görüldüğü gibi, dönüşümcü liderliğin, idealleştirilmiş etki, entelektüel uyarım, esin kaynağı olma ve bireyselleştirilmiş ilgi boyutlarının birlikte, örgüt iklimi ölçeğinin umursamaz öğretmen davranışları boyutunu yordama gücü istatistiksel olarak pozitif yönde ve orta düzeyde anlamlı bulunmuştur $(F=6.398, p<.05)$. Dönüşümcü liderliğin tüm boyutları birlikte, öğretmenlerin umursamaz öğretmen davranışları algılarındaki toplam varyansın yaklaşık \%9'unu açıklamaktadır. Dönüşümcü liderliğin esin kaynağı olma $(\beta=.484, p<.05)$ boyutu umursamaz öğretmen davranışları algılarını pozitif yönde ve anlamlı düzeyde yordamaktadır. Bunun yanında, bireyselleştirilmiş ilgi $(\beta=-.418, p<.05)$ boyutu umursamaz öğretmen davranışlarını negatif yönde ve anlamlı düzeyde yordamaktadır. İdealleştirilmiş etki ( $\beta=-.220, p>.05)$ ve entelektüel uyarım ( $\beta=.050, p>.05)$ boyutları umursamaz öğretmen davranışlarının anlamlı yordayıcısı değildir. Standardize edilmiş regresyon katsayısına göre $(\beta)$ yordayıcı değişkenlerin umursamaz öğretmen davranışlarının üzerindeki göreli önem sırası; esin kaynağı olma, bireyselleştirilmiş ilgi, idealleştirilmiş etki ve entelektüel uyarım olduğu görülmektedir. Regrasyon katsayılarının anlamlılığına ilişkin t-testi sonuçları incelendiğinde, umursamaz öğretmen davranışlarını dönüşümcü liderlik ölçeğinin esin kaynağı olma ve bireyselleştirilmiş ilgi değişkenlerinin anlamlı düzeyde yordadığı söylenebilir.

\section{Sonuç ve Tartışma}

$\mathrm{Bu}$ araştırmada, ilköğretim okulu öğretmenlerinin algılarına göre okul yöneticilerinin dönüşümcü liderlik davranışları ile örgüt iklimi arasındaki ilişkiler incelenmiştir. Araştırmanın sonuçları, dönüşümcü liderliğin örgüt iklimini yordayan önemli bir değişken olduğu düşüncesini doğrular niteliktedir.

Araştırma sonuçlarına göre, dönüşümcü liderlik boyutlarından bireyselleştirilmiş ilgi en yüksek düzeyde algılanan boyut olurken, en düşük düzeyde değerlendirilen boyut ise, esin kaynağı olma boyutu olmuştur. Serinkan (2003) ve Çelik (2010) yaptıkları çalışmalarda benzer sonuçlar elde etmiştir. Yapılan araştırma bulgularına göre en yüksek düzeyde algılanan boyut bireyselleştirilmiş ilgi olurken, esin kaynağı olma 
boyutu en düşük düzeyde değerlendirilen boyut olmuştur. $\mathrm{Bu}$ sonuçlar elde edilen araştırma bulgularını desteklemektedir. Keleş'in (2009) yaptığı araştırmada ise en yüksek ortalamaya sahip boyut esin kaynağı olma boyutu olurken, en düşük ortalamaya sahip boyut bireyselleştirilmiş ilgi boyutu olmuştur. Töremen ve Yasan (2010), Dursun (2009) ve Zeren (2007) yaptıkları araştırmada en yüksek düzeyde algılanan boyutu idealleştirilmiş etki boyutu olarak ifade etmişlerdir. Lider, astları yalnızca grubun bir üyesi olarak değil, aynı zamanda bir birey olarak gördüğü zaman astların kaygılarını dinler ve astlarına ilgi gösterir. Astların kendini geliştirmesi için önerilerde bulunur ve öğrenmeleri için onlara zaman ayırır. Lider astların bireysel farklılıklarını, gereksinimlerini ve yeteneklerini dikkate alırken, astlara başkalarının gereksinim ve yeteneklerini nasıl belirleyeceklerini de öğretir (Karip, 1998). Liderin, bireysel ihtiyaçları dikkate alması, bireysel farklılıklara önem vermesi, astların örgüt içinde değerli olduklarını hissetmelerini sağlayacaktır.

Örgüt iklimine ilişkin dağılımlara bakıldığında ise, en yüksek ortalama işbirlikçi öğretmen davranışları boyutunda olurken, en düşük ortalamanın umursamaz öğretmen davranışları boyutunda olduğu görülmektedir. Karataş'ın (2008) yaptığı çalışmada, örgüt ikliminin alt boyutlarına bakıldığında en yüksek ortalama uzak durma boyutunda olurken, en düşük ortalamanın ise işe dönüklük boyutuna ait olduğu görülmektedir. Özdemir vd. (2010) yaptıkları araştırmada ise, en yüksek ortalama akademik programda memnuniyet boyutunda olurken, en düşük ortalamanın öğretmenlerin olumsuz algılanması boyutunda olduğu görülmektedir. Samimi öğretmen davranışı, okul içerisindeki güçlü ve yakın sosyal destek ağını yansıtmaktadır. Öğretmenler birbirlerini çok iyi tanımakta, yakın arkadaşlıklar kurmakta ve sık sık bir araya gelmektedir (Hoy ve Miskel, 2010). Öğretmenlerin birbirleriyle olan sosyal ilişkilerinin sağlıklı olması, okul ortamında samimi bağların kurulması olumlu bir örgüt ikliminin oluşturulması açısından önem teşkil etmektedir. Örgüt içinde birlik ve beraberliğin sağlanması işlerin koordineli bir şekilde yürütülmesini de kolaylaştıracaktır. Bu durum bireysel ve örgütsel amaçların gerçekleştirilmesi yönünde örgüt çalışanlarını güdüleyecektir. Baykal'ın (2007) yaptığı araştırmada örgüt ikliminin alt boyutlarına bakıldığında en yüksek ortalamanın profesyonellik-içtenlik ve samimiyet boyutunda olduğu görülürken, en düşük ortalamanın ilgi boyutunda olduğu görülmektedir. Tahaoğlu'nun (2007) yaptığı çalışmada örgüt ikliminin alt boyutlarına bakıldığında en yüksek ortalama kendini işe verme boyutunda olurken, en düşük ortalamanın engellenme boyutunda olduğu görülmektedir.

Dönüşümcü liderlik anketinin tüm boyutları ile örgütsel iklimin destekleyici müdür davranışları, emredici müdür davranışları, samimi öğretmen davranışları, işbirlikçi öğretmen davranışları boyutları arasında pozitif yönde, anlamlı ilişki bulunmuştur. $\mathrm{Bu}$ bulgular, okul müdürlerinin dönüşümcü liderlik davranışlarını sergilemelerinin örgüt iklimini de olumlu yönde etkilediği şeklinde yorumlanabilir. Bireysel ihtiyaçlara önem verilmesi bireyin motivasyonunu artırarak olumlu iklimin oluşmasını ve verimliliğin artmasını sağlayacaktır. Dönüşümcü liderlik anketinin idealleştirilmiş etki, esin kaynağı olma ve bireyselleştirilmiş ilgi boyutları ile örgütsel 
ikliminin kısıtlayıcı müdür davranışları ve umursamaz öğretmen davranışları boyutları arasında negatif yönde, düşük düzeyde anlamlı bir ilişkiler bulunmuştur. Liderin, grubun üyelerini bir birey olarak görmesi, üyelerin ihtiyaçlarına önem vermesi üyelerin örgüt içinde olumsuz davranışlar sergilemesini engelleyerek üyelerin örgüt içerisinde zamanlarını verimli bir şekilde kullanmasını sağlayabilir. Araştırmaya katılan öğretmenlerin dönüşümcü liderlik ve örgüt iklimi algılarına ilişkin toplam puanları arasında pozitif yönde, orta düzeyde anlamlı bir ilişki bulunmuştur. Tahaoğlu (2007) yaptığ1 araştırmada ilköğretim okulu müdürlerinin sergiledikleri liderlik rollerinin örgüt iklimi üzerinde genel olarak pozitif, doğrusal, yüksek düzeyde ve anlamlı bir ilişkinin olduğu sonucuna varmıştır. Şen ve Yaşlıoğlu (2010) yaptıkları araştırmada, dönüşümcü liderlik ve örgütsel iklime ilişkin algılar arasında anlamlı ilişkilerin olduğu görülmektedir. Tuna'nın (1996) yaptığı bir araştırmada okul müdürlerinin yönetsel davranışlarıyla okul iklimi arasındaki ilişki saptanmıştır. Gültekin (2012) yaptığı çalışmada liderlik puanları ile örgüt ikliminin alt boyutları arasında anlamlı ilişkinin olduğu sonucuna varmıştır. Dönüşümcü liderin davranışları sayesinde çalışanlar liderin her zaman örgüt için yeni fırsatlar araştırdığını, değişim odaklı olduğunu görmekte ve bu durum çalışanların örgüt içerisinde olumlu bir iklim oluşturmasına neden olmaktadır. Yapılan çalışmalar dönüşümcü liderlik ve örgüt iklimi arasında ilişki olduğunu destekler niteliktedir.

Regrasyon sonuçları, dönüşümcü liderliğin, idealleştirilmiş etki, esin kaynağ olma ve bireyselleştirilmiş ilgi boyutlarının birlikte, örgüt ikliminin destekleyici müdür davranışları boyutunu anlamlı düzeyde yordadığını göstermiştir. Entelektüel uyarım destekleyici müdür davranışlarının anlamlı yordayıcısı olarak görülmemektedir. Destekleyici yönetim stiline sahip bir yönetici kendi davranışlarını birlikte çalıştığ insanların kişilik özelliklerine göre ayarlar ve onlara uygun bir çalışma ortamı oluşturmaya çalışır. Amacını çalıştığı kurumun amaçlarını gerçekleştirmek için etrafındaki insanları desteklemek olarak algılar. Başarılı olma hedefi onun için en iyi güdülenme ve özendirme aracıdır. Çalışanlarla çok yönlü iletişim kurmak, önerileri özenle dinlemek, örgütü yenileştirmek için bilimsel ve teknolojik gelişimleri yakından izlemek bu stil sahibi yöneticinin önemli özellikleridir (Akar, 2006). Çelik’in (2010) yaptığı araştırmada özbilinç yeterliliğinin dönüşümcü liderliğin alt boyutları üzerinde anlamlı bir yordayıcısı olduğu görülmektedir. Zeren (2007) yaptığı araştırmada dönüşümcü liderliğin alt boyutlarının örgütsel bağlılığın anlamlı yordayıcısı olduğu sonucuna varmıştır. Buluç (2009) yaptığı araştırmada okul müdürlerinin liderlik stillerinin boyutlarının, sınıf öğretmenlerinin örgütsel bağlılığını anlamlı olarak yordadığı sonucuna ulaşmıştır.

Dönüşümcü liderliğin, esin kaynağı olma boyutu, örgüt ikliminin emredici müdür davranışlarını anlamlı düzeyde yordadığı görülmektedir. İdealleştirilmiş etki, entelektüel uyarı ve bireyselleştirilmiş ilgi, emredici müdür davranışlarının anlamlı yordayıcısı değildir. Şişman'a (2012) göre; okul müdürü, okul için gerekli insan ve madde kaynaklarının sağlanmasından ve bunlar aracılığıyla öngörülen ürünlerin üretiminden, okul üyelerinin ve öğrencilerin performansından sorumlu kişidir. Ancak 
okulun toplam performans1, her şeyden önce okul içinde çalışan bireylerin performansına bağlıdır. Böylece okul müdürü, öncelikle okulun amaçlarının gerçekleşebilmesi için diğer insanların sahip oldukları bedensel ve zihinsel güçler yanında onların gönül güçlerini de harekete geçirmesi gereken kişi olmaktadır. Dönüşümcü liderliğin bireyselleştirilmiş ilgi boyutu umursamaz öğretmen davranışlarını negatif yönde anlamlı düzeyde yordarken, dönüşümcü liderliğin esin kaynağı olma boyutu örgüt ikliminin umursamaz öğretmen davranışları boyutunu pozitif yönde anlamlı düzeyde yordamaktadır.

Dönüşümcü liderliğin tüm boyutları kısıtlayıcı müdür davranışları ve samimi öğretmen davranışları boyutlarının anlamlı yordayıcısı değildir. İdealleştirilmiş etki ve entelektüel uyarım boyutları umursamaz öğretmen davranışlarının anlamlı yordayıcısı olarak görülmemektedir. Dönüşümcü liderliğin entelektüel uyarım boyutu örgüt ikliminin işbirlikçi öğretmen davranışları boyutunu pozitif yönde ve anlamlı düzeyde yordamaktadır. Araştırma sonuçlarına göre, idealleştirilmiş etki ve esin kaynağı olma ve bireyselleştirilmiş ilgi boyutları işbirlikçi öğretmen davranışlarının anlamlı yordayıcısı değildir. İşbirlikçi bir yönetici, yapılacak işleri çalışanların önüne serer, işbölümünün iş görenlerce yapılmasına kılavuzluk eder. Örgütün işlerinin çoğunluğu takımlarca yapılır ve takım başkanları ise üyeler tarafından seçilmektedir. Kararların planlanması, programlanması, iletişimin sağlanması, işlerin denetlenmesi ve değerlendirilmesi takımların yetki ve sorumluluğuna bırakılmıştır (Başaran, 1992).

Araştırmanın önemli sonuçları şu şekilde özetlenebilir: 1) Dönüşümcü liderliğin örgüt iklimini yordayan önemli bir değişken olduğu görülmektedir. 2) Dönüşümcü liderlik boyutlarından bireyselleştirilmiş ilgi en yüksek düzeyde algılanan boyut olurken, örgüt iklimine ilişkin dağılımlara bakıldığında ise, en yüksek ortalama işbirlikçi öğretmen davranışları boyutundadır. 3) Öğretmenlerin dönüşümcü liderlik ve örgüt iklimi algılarına ilişkin toplam puanları arasında pozitif yönde, orta düzeyde anlamlı bir ilişki bulunmuştur.

\section{Öneriler}

Araştırma sonuçlarına dayalı olarak, okul yöneticilerinin dönüşümcü liderlik özelliklerine sahip olması olumlu örgüt iklimi açısından önemlidir. Okul yöneticilerinin dönüşümcü liderlik davranışlarını sergilememesi okulun amaçlarına ulaşmasını zorlaştırabilir. Araştırma ilişkisel tarama modelinde olduğu için neden-sonuç ilişkisinden ziyade karşılıklı ilişskiler vurgulanmıştır. Okul yöneticilerinin dönüşümcü liderlik özellikleri ile örgütsel iklim arasında neden-sonuç ilişkilerinin ortaya konulabileceği araştırmalar yapılabilir. Araştırma sonuçlarını destekleyecek nitel veriler kullanılabilir. Okul yöneticilerine dönüşümcü liderlik özellikleri kazandırılması açısından dönüşümcü liderlik ile ilgili bilgilerin yer aldığı hizmet içi eğitim çalışmaları ve seminerler düzenlenebilir. Okul müdürleri öğretmenlerle iletişim halinde olarak örgütsel iklim ile ilgili öğretmenlerden dönüt alabilirler. 


\section{Kaynakça}

Adair, J., \& Reed, P. (2008). Patronlar Değil Liderler (Çev. G. Doğancalı). İstanbul: Babıli Kültür Yayıncılık.

Akar, A. (2006). Illköğretim okullarında öğretmen algılarına göre yöneticilerin, yöneticilik becerilerinin örgüt iklimine katklsl: Ankara ili örneği (Yayınlanmamış yüksek lisans tezi). Gazi Üniversitesi, Ankara.

Aksoy, H. (2006). Örgüt ikliminin motivasyon üzerine etkisi (Yayınlanmamış yüksek lisans tezi). Marmara Üniversitesi, İstanbul.

Altun, S. (2003). İlköğretim okulu müdürlerinin dönüşümcü liderliğe verdikleri önem ve uygulama düzeyleri. http://www.ilköğretim-online.org.tr. Erişi Tarihi: 05.08.2013.

Aydın, M. (2010). Eğitim yönetimi. (9. Baskı). Ankara: Hatipoğlu Basım.

Başaran, İ. (1992). Yönetimde insan ilişkileri. Ankara: Gül Yayınevi.

Başaran, İ. (2000). Ĕgitim yönetimi. (4. Bask1). Ankara: Feryal Matbaacılık.

Baykal, İ. (2007). İlköğretim okullarının örgüt ikliminin bazı değişkenler açısından incelenmesi (Yayınlanmamış yüksek lisans tezi). Ege Üniversitesi, İzmir.

Bennis, W. (2003). One becoming a leader (Çev. U. Teksöz). (4. Baskı).

İstanbul: Sistem Yayıncılık.

Bilir, M. (2007). Öğretmen algllarına göre ilköğretim okul yöneticilerin dönüşümcü liderlik özellikleriyle öğretmenlerin iş doyumu ilişkisinin incelenmesi (Yayınlanmamış yüksek lisans tezi). Selçuk Üniversitesi, Konya.

Büte, M. (2011). Algılanan örgüt ikliminin etik olmayan davranışlar üzerindeki etkilerinin belirlenmesine yönelik bir araştırma. Atatürk Üniversitesi İktisadi ve İdari Bilimler Dergisi, 25(2), 103-122.

Buluç, B. (2009). Sınıf öğretmenlerinin algılarına göre okul müdürlerinin liderlik stilleri ile örgütsel bağlılık arasındaki ilişki. Kuram ve Uygulamada Eğitim Yönetimi, 15(57), 5-34.

Bursalığlu, Z. (2011). Okul Yönetiminde Yeni Yapı ve Davranış (16. Baskı). Ankara: Pegem Yayıncilık.

Çekmecelioğlu, H. (2007). Örgüt İkliminin İş Tatmini ve İşten Ayrılma Niyeti Üzerindeki Etkisi. Dokuz Eylül Üniversitesi Sosyal Bilimler Enstitüsü Dergisi, 9(1), 79-97.

Çelik, V. (2003). Eğitimsel liderlik. (3. Baskı). Ankara: PegemA Yayınları.

Çelik, Ö. (2010). Okul yöneticilerinin özbilinç yeterliliği ile dönüşümcü liderlik özellikleri arasındaki ilişki (Yayınlanmamış yüksek lisans tezi). Sakarya Üniversitesi, Sakarya.

Dursun, Y. (2009). Öğretmenlerin tükenmişlik düzeyleri ile yöneticileri için algıladıkları dönüşümcü ve etkileşimci liderlik stilleri arasındaki ilişki: 
Karabük ilkögretim okulları örneği (Yayınlanmamış yüksek lisans tezi). Gazi Üniversitesi, Ankara.

Emeksiz, Ö. (2003). İlköğretim okulu öğretmenlerinin okul iklimi ve liderlik etkenlerine ilişkin görüşleri (Yayımlanmamış yüksek lisans tezi). Afyon Kocatepe Üniversitesi, Afyon.

Gottfredson, G. D., Gottfredson, D. C., Payne, A. A, \& Gottfredson, N. C. (2005). School Climate Predictors of School Disorder: Results From A National Study of Delinquency Prevention In Schools. Journal of Research In Crime and Delinquency, 42(4), 412-444.

Gültekin, C. (2012). Okul yöneticilerinin liderlik stillerinin okul iklimi üzerine etkisi (Yayınlanmamış yüksek lisans tezi). Maltepe Üniversitesi, İstanbul.

Herriegel, D., Slocum, J. W., \& Woodman, R. W. (1995). Organizational behavior, West Publishing Company: 378.

Holloway, J. B. (2012). Leadership Behavior and Organizational Climate: An Empirical Study in a Non-profit Organization. Emerging Leadership Journeys, 5(1), 9-35.

Karataş, S. (2008). Okul müdürlerinin etkililiği ve okul iklimi (Yayınlanmamış yüksek lisans tezi). Yedi Tepe Üniversitesi, İstanbul.

Karip, E. (1998). Dönüşümcü liderlik. Kuram ve uygulamada eğitim yönetimi, 16, 443465.

Keleş, Ö. (2009). İlköğretim okulu müdürlerinin dönüşümcü liderlik özelliklerini gösterme düzeylerine ilişkin öğretmen görüşleri: Muğla ili örneği (Yayınlanmamış yüksek lisans tezi). Muğla Üniversitesi, Muğla.

Marks, H. M., \& Printy, S. N. (2003). Principal leadership and school performance: An integration of transformational and instructional leadership. Educational Administration Quarterly, 39(3), 370-397.

Mercan, N., Özler, D. ve Yılmaz, A. (2008). Mobbing ve örgüt iklimi ile ilişkisine yönelik ampirik bir araştırma. Elektronik Sosyal Bilimler Dergisi, 7(26), 334-357.

Moolenaar, N. M., Daly, A. D., \& Sleegers, P. J. C. (2010). Occupying the principal position examining relationships between transformational leadership social network and schools' innovative climate. Educational Administration Quarterly, 46(5) 623-670.

Önen, L. (2008). Örgüt iklimi üzerinde kültürün etkisi (Yayınlanmamış yüksek lisans tezi). Marmara Üniversitesi, İstanbul.

Özdemir, S., Sezgin, F., Şirin, H., Karip, E. ve Erkan, S. (2010). İlköğretim okulu öğrencilerinin okul iklimine ilişkin algılarını yordayan değişkenlerin incelenmesi. Hacettepe Üniversitesi Eğitim Fakültesi Dergisi, 38, 213-224.

Pepper, K. ve Thomas, L. H. (2002). Making a change: The effects of the leadership role on school climate. Learning Environments Research, 5(2), 155-166.

Serinkan, C. (2003). Toplam kalite yönetimi ile dönüşümcü liderlik ilişkisi (Yayınlanmamış doktora tezi). İstanbul Üniversitesi, İstanbul. 
Şahin, B. (2009). Örgütsel gelişmenin sağlanmasında dönüşümcü liderlerin rolü. Dokuz Eylül Üniversitesi Sosyal Bilimleri Enstitüsü Dergisi, 11(3), 97-118.

Şen, Y. ve Yaşlıoğlu, M. (2010). Dönüşümcü liderliğin yeniliği destekleyici örgüt iklimi üzerindeki etkisini belirlemeye yönelik bir araştırma. Yönetim Yılı Dergisi, 21(66), 97-117.

Şişman, M. (2012). Eğitimde mükemmellik arayışı: Etkili okullar (3.Bask1). Ankara: Pegem Yayıncılik.

Şişman, M. (2012). Öğretim liderliği (4. Baskı). Ankara: Pegem Yayıncılık.

Tahaoğlu, F. (2007). İlköğretim okulu müdürlerinin liderlik rollerinin örgüt iklimi üzerine etkisi: Gaziantep ili örneği (Yayınlanmamış yüksek lisans tezi). Gaziantep Üniversitesi, Gaziantep.

Taymaz, H. (2007). İlköğretim ve ortaöğretim okul müdürleri için okul yönetimi (8. Bask1). Ankara: Pegem Yayıncılık.

Töremen, F. ve Yasan, T. (2010). İlköğretim okulu yöneticilerinin dönüşümcü liderlik özellikleri: Malatya ili örneği. Pamukkale Üniversitesi Ĕ̆itim Fakültesi Dergisi, 28, 27-39.

Tuna, Z. (1996). Okul müdürlerinin yönetsel davranışlarının örgüt iklimine etkisi (Yayımlanmamış yüksek lisans tezi). Ankara Üniversitesi, Ankara.

Ulutaş, S. (2010). Kriz yönetimi ve dönüşümcü liderlik (Yayınlanmamış yüksek lisans tezi) Dokuz Eylül Üniversitesi, İzmir.

Hoy, W. K. and Miskel. C. G. (2010). Educational administration theory, research and practice. (Çev. S. Turan). (7. Baskı). Ankara: Nobel Yayın Dağıtım.

Yapıcıer, İ. (2007). Örgüt ikliminin oluşmasında okul yöneticilerinin kişisel ve yönetselözelliklerinin rolü (Yayınlanmamış yüksek lisans tezi). Gazi Osman Paşa Üniversitesi, Tokat.

Yaşar, Ö. (2005). Örgütsel güvenin örgüt iklimine etkisi; gaziantep sanayi işletmelerinde bir uygulama (Yayınlanmamış yüksek lisans tezi). Gaziantep Üniversitesi, Gaziantep.

Yavuz, E. (2008). Dönüşümcü ve etkileşimci liderlik davranışının örgütsel bă̆llliğa etkisinin analizi (Yayınlanmamış doktora tezi). Gazi Üniversitesi, Ankara.

Yılmaz, F. ve Altınkurt, Y. (2013). Örgütsel iklim ölçeğinin Türkçe’ye uyarlanması: Geçerlik ve Güvenirlik Çalışması. Trakya Üniversitesi Eğitim Fakültesi Dergisi, 3(1), 1-11.

Zeren, H. (2007). Illkögrretim okulu müdürlerinin dönüşümcü liderlik stilleri ile bu okullarda görevli ögretmenlerin örgütsel bă̆lllı̆̆l arasındaki ilişki: Şanlı Urfa ili örneği (Yayınlanmamış yüksek lisans tezi). Harran Üniversitesi, Şanlı Urfa. 